\title{
SURVEY OF WIND POWER POTENTIAL FOR WIND-BASED ELECTRICITY AT MAKAMBAKO, IRINGA TANZANIA
}

\author{
RMR Kainkwa \\ Physics Department, University of Dar es Salaam \\ P. O. Box 35063, Dar es Salaam, Tanzania, Phone +255 222410258 \\ Email: kainkwa@udsm.ac.tz
}

\begin{abstract}
The potential for wind-generated electricity is examined using 22 months wind data collected from a prospective site located in the southern highlands of Tanzania. While the data for the year 2001 was from March to December that of 2002 was for all the twelve months of the year. Characteristics of monthly and annual wind speed and direction are systematically investigated based on hourly time-series data using Windographer software. The Weibull shape factors $k$ corresponding to a height of $50 \mathrm{~m}$ were found to be 3.10 and 3.80 while the scale factors c were 11.06 and $12.27 \mathrm{~m} / \mathrm{s}$ for the years 2001 and 2002, respectively. The wind power potential at the location is established to be substantially high as the mean power density and energy content at the site are 8,788 and $6,839 \mathrm{~W} / \mathrm{m}^{2}$, and 78,986 and $59,908 \mathrm{kWh} / \mathrm{m}^{2} / \mathrm{yr}$, respectively, for the years 2001 and 2002. The large difference between the mean values for the two years is due to the fact that the set of data for first year was for a period of 10 months while that of the later year was for 12 months.
\end{abstract}

\section{INTRODUCTION}

Generation of electricity world wide is mainly from fossil fuels, renewable and nuclear sources. Fossil fuel sources currently provide a larger share of world electricity generation than any other energy resource and are expected to remain in that position for more than a decade (http://www.eia.doe.gov/cneaf/electricity/epa /epat1p1.html - June 2008). The demerits of fossils are that they have high price growth rates apart from being depleted at a faster rate than they replenish and also destructive to the environment. These demerits of fossil fuels have compelled many electricity developers to opt for renewable energy resources that are inexhaustible and have less adverse impact to the environment. Presently, renewable energy resources are the third largest contributors to global electricity production (Balat 2006) in which wind power is the fastest-growing renewable energy resource of electricity.

In the early 1990 s slightly more than $90 \%$ of the electricity consumed in Tanzania was generated from hydro-plants. This trend continued up to the end of 2003 in which the share of hydropower increased to about $96 \%$ (http://www.tanesco.com - June 2008). However, the rivers on which the hydro plants are constructed are rain fed and as such during the dry seasons and extended droughts, available water cannot suffice to operate the generators at their rated capacities. Moreover, irrigation schemes, most of which are situated upstream the dams, are very necessary during the dry season and as such there is normally a challenge between the appropriate uses of water in either electric generation or irrigation systems.

There was an extended drought in the late 2005 and the whole of 2006 during which period electric power rationing was the order of the day. In addressing to this shortage of electricity, the government of Tanzania in collaboration with the Tanzania Electricity Supply Company Limited (TANESCO) that is responsible for generating electricity opted to generate electricity from natural gas and diesel. By the end of December 2006 the share of fossil fuel sources in electricity 
Kainkwa - Survey of wind power potential for wind-based electricity ...

generation had risen dramatically to $40.26 \%$ as detailed in Table 1 . Since at present the country does not produce petroleum products, the use of diesel in generating electricity places a burden on the national economy due to the high cost of the imported fossil fuels.

Table 1: Installed Grid Electricity Generation Capacity in Tanzania as per $31^{\text {st }}$ December 2006.

\begin{tabular}{|c|c|c|c|c|}
\hline SN & PLANT & $\begin{array}{l}\text { HYDRO, DIESEL } \\
\text { OR GAS }\end{array}$ & $\begin{array}{c}\text { INSTALLED } \\
\text { CAPACITY (MW) }\end{array}$ & OWNERSHIP \\
\hline 1 & Kidatu & Hydropower Plant & 204 & TANESCO \\
\hline 2 & Kihansi & Hydropower Plant & 180 & TANESCO \\
\hline 3 & Mtera & Hydropower Plant & 80 & TANESCO \\
\hline 4 & New Pangani Falls & Hydropower Plant & 68 & TANESCO \\
\hline 5 & Hale & Hydropower Plant & 21 & TANESCO \\
\hline 6 & Nyumba ya Mungu & Hydropower Plant & 8 & TANESCO \\
\hline 7 & SONGAS & Gas Turbines & 182 & Private \\
\hline 8 & IPTL & Diesel - run plant & 100 & Private \\
\hline 9 & Aggreko & Gas Turbines & 40 & Private \\
\hline 10 & Dowans Holdings & Gas Turbines & 22 & Private \\
\hline \multirow[t]{6}{*}{11} & $\begin{array}{l}\text { Grid Connected Diesel } \\
\mathrm{P} / \text { Stations }\end{array}$ & Diesel - run plants & 34 & TANESCO \\
\hline & & TOTAL & 939 & \\
\hline & Numbers 1 to 6 & Hydropower Plant & 561 & \\
\hline & Number 7 to 12 & Fossil Fuels & 378 & \\
\hline & & Total & 939 & \\
\hline & & $\begin{array}{l}\text { Ratio of Fossil to } \\
\text { total }\end{array}$ & 0.4026 & \\
\hline
\end{tabular}

Sources: http://www.tanesco.com/generation.html - June 2008.

The electric energy crisis in Tanzania compels the country to search for alternative renewables in order to stabilize the energy matrix and reduce the overdependence on precipitation and the fossil fuel sources. Solar radiation and wind are renewable energy resources that are plentiful in the country but their magnitudes have not yet been measured and analysed to an encouraging stage. Some preliminary measurements show that Tanzania has a reasonably high wind power (Kainkwa and Uiso 1989, Kainkwa 2000), but this potential has not been used for many years because the type of available wind data is not sufficient to convince the government to invest in wind-generated electricity. Before one can decide to harvest the wind energy resource, that is very variable with time and space, systematic investigation of its characteristics needs to be done. The main objective of this paper is to investigate the wind power potential at Makambako, a site located in the southern highland of Tanzania, for future wind-based electricity generation projects. Wind data averaged on hourly basis for a period of 22 months is used as the primary information. 


\section{TECHNIQUES OF ASSESSING WIND RESOURCE CHARACTERISTICS}

The best places to install wind turbines are areas that have strong and frequent winds. A precise knowledge of wind characteristics is therefore a pre-requisite for the efficient planning and implementation of any wind energy project. The characteristics of wind resource can totally be described by its direction and speed. Dominating wind direction is normally determined by the use of a wind rose which is a polar scheme that represents the percentage of time that the wind direction falls within each sector of the compass. Wind speed is the most important aspect of the wind resource, because there is a direct relationship between wind speed and wind turbine output. The character of wind speed can fully be described by investigating the change in wind speed with height, average wind speed, wind direction, wind speed distribution and turbulent intensity.

The increase in wind speed with altitude is most dramatic near the surface and is affected by topography, surface roughness, and upwind obstacles such as trees or buildings. Usually, the increase of wind speeds with increasing height follows a logarithmic profile that can be reasonably approximated by the wind profile power law. It is often used as a substitute for the logarithmic wind profile when surface roughness is not available. The power law is an empirical relationship between wind speeds at two heights that can be expressed as (Gipe 1999):

$$
\frac{V_{X}}{V_{r}}=\left(\frac{Z_{X}}{Z_{r}}\right)^{\alpha}
$$

where $V_{X}$ is the wind speed $(\mathrm{m} / \mathrm{s})$ at height $Z_{X}(\mathrm{~m})$, and $V_{r}$ is the known wind speed at a reference altitude, $Z_{r}$. The exponent, $\alpha$ is an empirically derived coefficient that varies depending upon the stability of the atmosphere and for neutral stability conditions, $\alpha$ is approximately $1 / 7$, a value that is often quoted as a reasonable value for the power law exponent in typical British countryside (Peterson and Hennessey 1978). The $\alpha$, on a tropical coast was found by Hsu et al. (1994) to range from 0.15 for stability class A to greater than 0.40 for class $F$.

In places where trees or structures obstruct the near-surface wind, the use of a constant $1 / 7$ exponent may yield quite erroneous estimates because it was derived for turbulent flow over a flat plate, and the logarithmic wind profile is preferred (Counihan 1975, Touma 1977). In the neutral atmospheric surface layer where turbulence is generated primarily in a mechanical way, logarithmic wind profile is described by the relation (WMO 1981):

$$
V_{X}=\frac{V_{*}}{\kappa} \ln \frac{Z_{X}}{Z_{o}}
$$

where $V_{*}$ is the friction (or shear) velocity $\left(\mathrm{m} \mathrm{s}^{-1}\right), Z_{o}$ is the roughness length $(\mathrm{m})$ and $=0.4$ is the von Karman constant.

$V_{r}$ at another level say $Z_{r}$ is expressed as:

$$
V_{r}=\frac{V_{*}}{\kappa} \ln \frac{Z_{r}}{Z_{o}}
$$

From Equations 2 and 3 the wind speed at a height $Z_{X}$ can be expressed as:

$$
V_{X}=\frac{\ln \frac{Z_{X}}{Z_{o}}}{\ln \frac{Z_{r}}{Z_{o}}} V_{r}
$$

Wind speed distribution can be denoted by a plot of the wind speed probability distribution function to reveal the character of this apparently random variation. The two-parameter Weibull distribution is often used to characterize wind regimes because it has been found to provide a good fit with measured data. The probability density function, $f(v)$, is given by (WMO 1981): 


$$
f(V)=\frac{k}{c}\left(\frac{V}{c}\right)^{k-1} \exp \left[-\left(\frac{V}{c}\right)^{k}\right] 5
$$

where $V$ is the wind speed, $k$ is a dimensionless shape factor, and $\mathrm{c}$ is a scale parameter with the same units as $V$.

The two parameters $c$ and $k$ are linked to the average wind speed by the relation:

$$
V=c \Gamma\left(\frac{1}{k}+1\right) \quad 6
$$

where $\Gamma$ is the gamma function.

Any Weibull distribution can therefore be portrayed by the average wind speed and the Weibull $k$ value. The Weibull $k$ value is an indication of the breath of the distribution of wind speeds. The lower $k$ value corresponds to the broader distribution. In addition, lower average wind speed corresponds to lower Weibull $k$ values, and vice versa.

Power from the wind can be characterized either as the available wind power density, $\mathrm{P}_{\mathrm{a}}$, or the extractable wind power density, $\mathrm{P}_{\mathrm{e}}$. The available power density is the power available in a cross sectional area perpendicular to the wind stream of density $\rho$ moving at a speed $\mathrm{V}$. The power $\mathrm{P}_{\mathrm{a}}$ of the wind at speed $V \mathrm{~m} / \mathrm{s}$ per unit area perpendicular to the wind direction is given as (Gipe 1999):

$$
P_{a}=\frac{1}{2} \rho V^{3}
$$

Extractable wind power density on the other hand, is the power which can be extracted from the wind stream depending on the available wind power and on the operating characteristics of the wind turbine. The extractable power density is given by the equation (Gipe, 1999):

$$
P_{e}=C_{p} \frac{1}{2} \rho V^{3}
$$

where $C_{p}$ is the power coefficient with the maximum value of 0.593 , which is the Betz limit or the Betz coefficient. The wind energy density $E$ per period under consideration can be calculated by the relation (Gipe 1999):

$\mathrm{E}=\mathrm{Pt}$

where $\mathrm{t}$ is the total time in seconds in that period and $\mathrm{P}$ is the estimated power density.

\section{MATERIALS AND METHODS}

Wind speed and direction were measured, respectively, by anemometer (type AN1) and windvane (type WD1) (DELTA-TDEVICES, UK). The two wind sensors were positioned $7 \mathrm{~m}$ above the ground level. The data were recorded on hourly basis and the one that is used in this article covered the period from $1^{\text {st }}$ March 2001 to $31^{\text {st }}$ December 2002.

Wind speeds at a height $Z_{X}=50 \mathrm{~m}$, that corresponds to the average hub height of a standard wind turbine, were determined using Equation 4 in which the roughness length, $Z_{o}$, of the area was taken to be 0.25 $\mathrm{m}$ (WMO 1981). This value of the roughness length matches with the vegetation features of the area that was composed of isolated trees with some grass and is also in line with standard values given in WMO (1981). The height $Z_{r}$ was taken to be $7 \mathrm{~m}$ the level at which wind speed and direction were collected. The wind profile power law was not used in the vertical extrapolation of the wind speed because the atmosphere was not stable all the time of the measurement and the physical characteristics of the underlying surface was not smooth enough to use this simple power-law wind profile.

The dominant wind direction, the monthly average wind speeds, probability distribution function, mean power density, mean energy content, Weibull $k$ and $c$ parameters were determined from the hourly records using windographer, which is a powerful software tool for analyzing wind data

(http://www.mistaya.ca/products/windograp her.htm - 2007). 


\section{RESULTS AND DISCUSSION}

Wind frequency roses for the two years data were plotted and they are as depicted in Fig. 1. The wind frequency roses show that the dominating wind direction for the two years was approximately between $54^{\circ}$ and $75^{\circ}$.
When designing a wind farm for this site, it would be important to propose a layout of the turbine row to be perpendicular to the prevailing wind directions so as to minimize the obstruction between individual turbines.

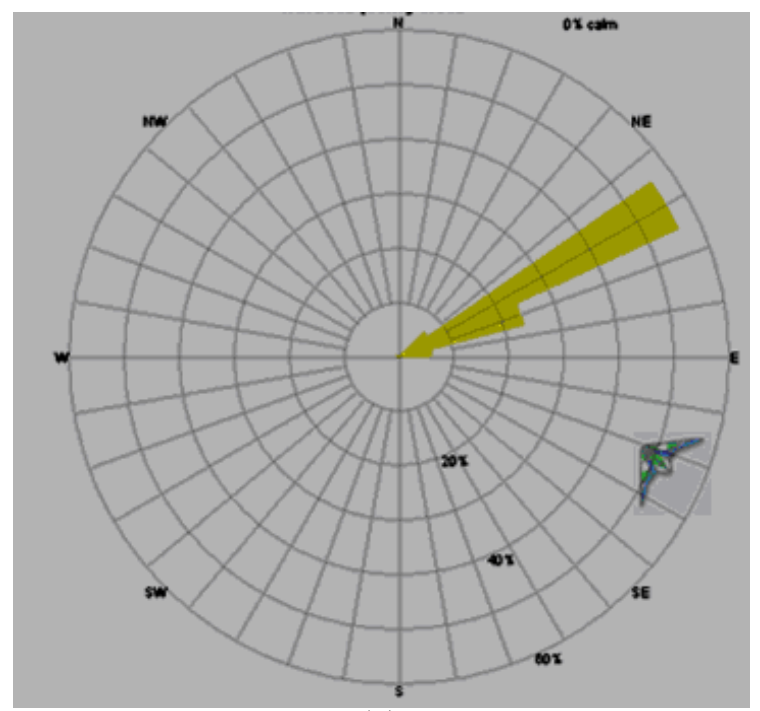

(a)

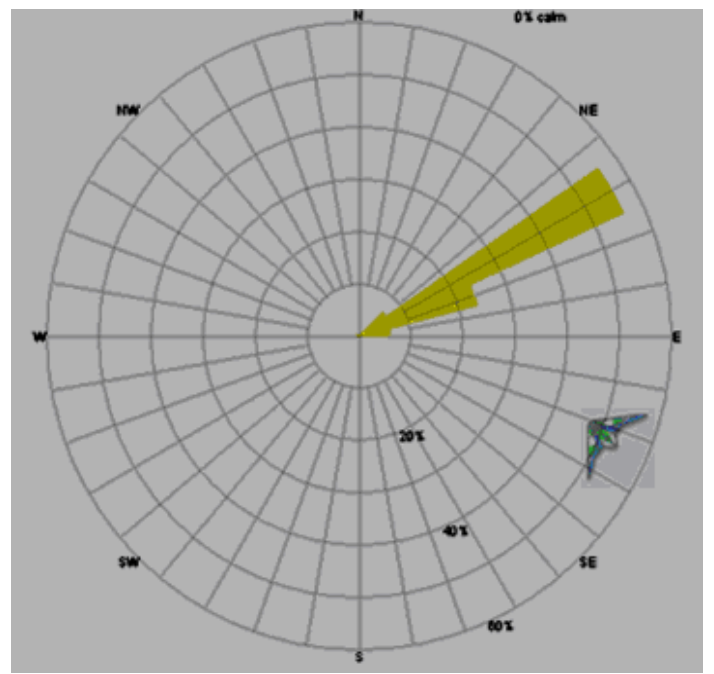

(b)

Figure 1: (a) and (b) are wind frequency roses for the years 2001 and 2002 respectively. 
Kainkwa - Survey of wind power potential for wind-based electricity ...

Fig. 2 demonstrates the monthly and annual average wind speed along with the maximum and minimum daily averages and maximum and minimum instantaneous wind speed for each month. The two figures have analogous patterns in that there is an increase of wind speed from May to October in which the peak value is attained in October. The maximum and minimum values for both years are about 24 and 0 $\mathrm{m} / \mathrm{s}$, respectively. The minimum was attained in January 2002, a month that is within the calm season of the zone (Kainkwa and Uiso 1989). Probability distribution functions of the wind speed frequency for the two years are shown in Fig. 3 in which (a) and (b) are respectively for 2001 and 2002. Probability distribution function in the first year is symmetrical while that of the second year is slightly skewed to the right. The difference is most likely due to the missing low wind speed data in the months of January and February for the year 2001 and inclusion of the data in the following year.
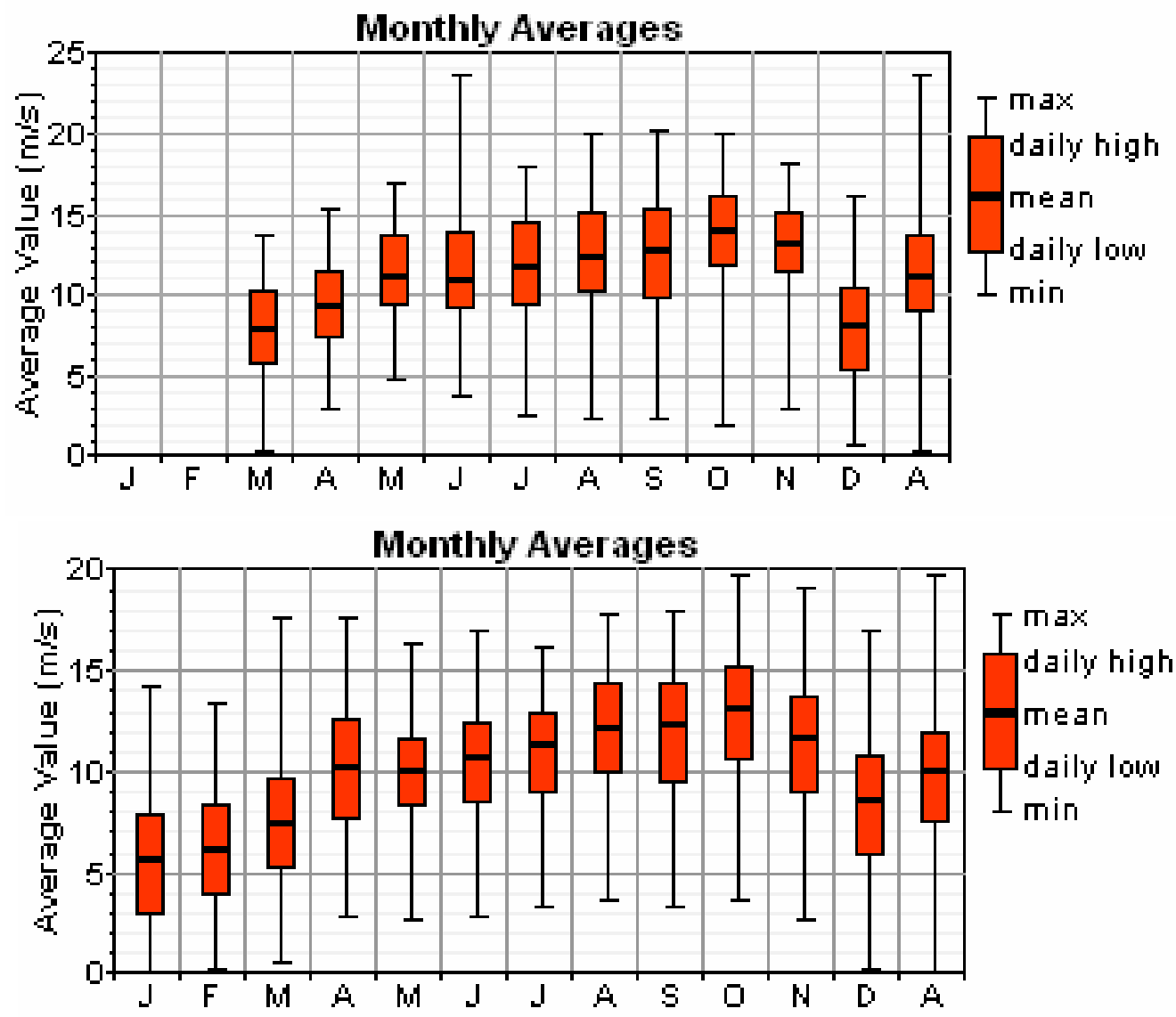

Figure 2: (a) and (b) are monthly mean wind speed (m/s) for 2001 and 2002, respectively at $50 \mathrm{~m}$ height. The data for the year 2001 and 2002 were respectively for a period of 10 and 12 months. The letter $\mathbf{A}$ after the month of December (D) stands for the annual mean value. 


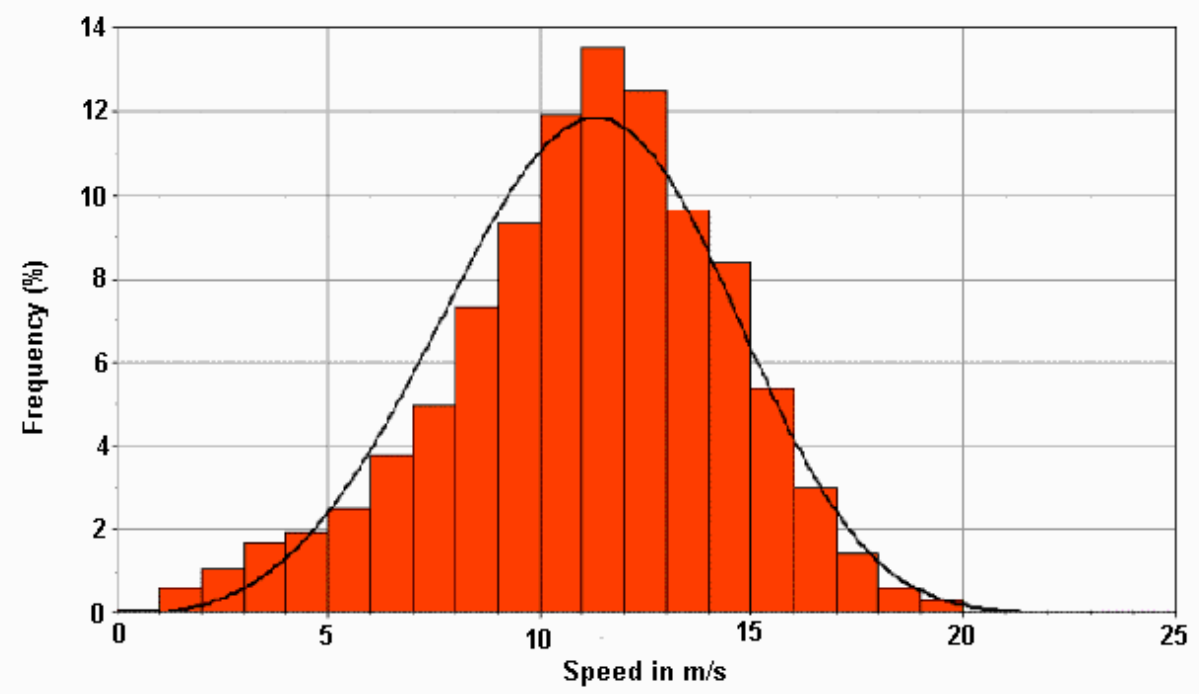

(a)

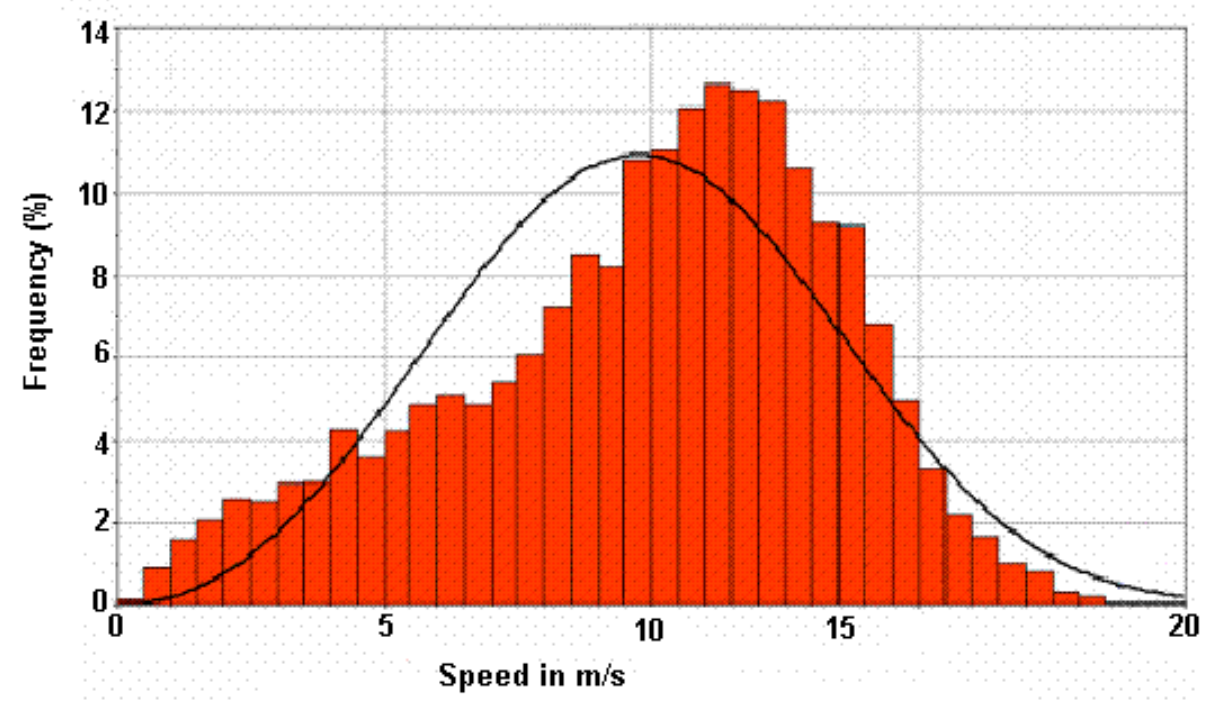

(b)

Figure 3: Probability distribution functions for (a) 2001 and (b) 2002. While the bars represent the frequency of the corresponding wind speed, the smooth curve depicts the expected Gaussian distribution of the data.

Table 2 shows that at the site the annual mean wind speed were 11.10 and $9.93 \mathrm{~m} / \mathrm{s}$, in 2001 and 2002, respectively. These values are close to the rated wind speeds of current wind turbines as for example that of $\mathrm{Suzlon} \quad$ being $12 \quad \mathrm{~m} / \mathrm{s}$
(http://www.suzlon.com/WindTurbines.html ?cp=2 3 - June 2008). The table shows further that the Weibull parameters were $\mathrm{k}=3.80$ and $\mathrm{c}=12.27 \mathrm{~m} / \mathrm{s}$ for 2001 and those in 2002 were 3.10 and $11.06 \mathrm{~m} / \mathrm{s}$. Mean power density and energy content at the site 
Kainkwa - Survey of wind power potential for wind-based electricity ...

are 8,788 and $6,839 \mathrm{~W} / \mathrm{m}^{2}$, and 78,986 and $59,908 \mathrm{kWh} / \mathrm{m}^{2} / \mathrm{yr}$, respectively, for the years 2001 and 2002. Turbulent intensity, which can be expressed as the coefficient of variation in terms of percentage, was evaluated to be 29.90 and $36.20 \%$, correspondingly for 2001 and 2002. The energy content at the site calculated for the period under study gives some light on the available wind energy at the site which is fairly high. It should be noted that the major difference in the wind parameters shown in Table 2 for the two years is that the wind data for the year 2002 was for a period of 12 months while that of the year 2001 was for a period of 10 months. These results are therefore an indicative assessment of wind energy potential at the site and the actual potential can only be confirmed by collecting data for a period of at least ten years.

Table 2: $\quad$ Summary of the calculated wind speed parameters for 2001 and 2002 at $50 \mathrm{~m}$ above

\begin{tabular}{clcc}
\multicolumn{3}{c}{ ground level. } \\
\hline & VARIABLE & 2001 & 2002 \\
\hline 1 & Mean wind speed $(\mathrm{m} / \mathrm{s})$ & 11.10 & 9.93 \\
2 & Mean power density $\left(\mathrm{W} / \mathrm{m}^{2}\right)$ & 8,788 & 6,839 \\
3 & Mean energy content $\left(\mathrm{kWh} / \mathrm{m}^{2} / \mathrm{yr}\right)$ & 78,986 & 59,908 \\
4 & Weibull k & 3.80 & 3.10 \\
5 & Weibull c $(\mathrm{m} / \mathrm{s})$ & 12.27 & 11.06 \\
6 & Coefficient of variation $(\%)$ & 29.90 & 36.20 \\
\hline
\end{tabular}

\section{CONCLUSION}

In wind-generated electricity the principal production cost is the capital spent for initial construction and installation. Since wind is a free fuel the only ongoing cost is for maintenance. When the wind industry first began to develop in California in the early $1980 \mathrm{~s}$, the cost of wind-generated electricity was 38 US cents $/ \mathrm{kWh}$ but at present the cost has declined to 4 US cents/kWh

(http://www.awea.org/faq/cost.html - June $\begin{array}{llllll}2 & 0 & 0 & 8\end{array}, \quad \underline{\text { http://www.earth- }}$ policy.org/Indicators/indicator10.htm - June 2008). In Tanzania the generation cost by Songas is 5.5, while that by TANESCO's own generators is between 7 to 9 and that by IPTL is 12 US cents $/ \mathrm{kWh}$ (http://www.songas.com/FAQ.htm - June 2008 ,

http://www.tanesco.com/generation.html -

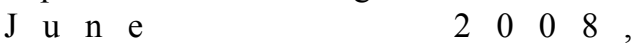
http://www.psiru.org/report/2006-11-E-

Eafrica.com - June 2008). This information shows that the average unit cost of generating electricity in Tanzania at present is above that for wind-generated electricity. It is therefore recommended that when setting electric energy strategy of the country, wind power should also be considered because it is ample, renewable and clean energy source whose unit production cost is below the present mean generation cost.

\section{ACKNOWLEDGEMENT}

The work was funded through Sida/SAREC Support to the Faculty of Science, University of Dar es Salaam and technically supported by the Department of Physics.

\section{REFERENCES}

Balat M 2006 Electricity from Worldwide Energy Sources. Energy Sources, Part B: Economics, Planning, and Policy. 1(4): $395-412$.

Counihan J 1975 Adiabatic atmospheric boundary layers: A review and analysis of data from the period 1880-1972. Atmospheric Environment. 79: 871-905.

Gipe P 1999. Wind Energy Basics: A Guide to small and micro wind systems. Chelsea Green Publishing Company. 
Hsu SA Meindl EA and Gilhousen DB 1994 Determining the power-law windprofile exponent under near-neutral stability conditions at sea. Journal of Applied Meteorology.33: 757-765.

http://www.awea.org/faq/cost.html - June 2008. A website for American Wind Energy Association (AWEA).

http://www.earth-

policy.org/Indicators/indicator10.htm. June 2008 A website for Earth Policy Institute.

http://www.eia.doe.gov/cneaf/electricity/epa/ epat1p1.html - June 2008 Energy Information Administration: Electric Power Annual with data for 2006 Report Released: October 22, 2007.

http://www.mistaya.ca/products/windograph er.htm - 2007 A website for mistaya engineering inc.

http://www.psiru.org/report/2006-11-E-

Eafrica.com - June 2008 A website for Public Services International Research Unit (PSIRU).

http://www.songas.com/FAQ.htm - June 2008 A Website for Songas Company LTD.
(http://www.suzlon.com/WindTurbines.html ? $\mathrm{cp}=2$ 3) - June 2008 A website for SUZLON Company.

http://www.tanesco.com/generation.html June 2008 A website for Tanzania Electricity Supply Company Limited (TANESCO).

Kainkwa RMR and Uiso CBS 1989 Survey of wind pattern and available wind power in Tanzania. Solar and Wind Technology. 6(6): 729 - 732.

Kainkwa RMR 2000 Wind Speed Pattern and the Available Wind Power at Basuto, Tanzania. Renewable Energy. 21(2000) 289-295.

Peterson EW and Hennessey JP Jr 1978 On the use of power laws for estimates of wind power potential. Journal of Applied Meteorology. 17: 390-394.

Touma JS 1977 Dependence of the wind profile power law on stability for various locations. J. Air Pollution Control Assoc. 27: 863-866.

WMO World Meteorological Technical Note No 1751981 Meteorological Aspect of the Utilization of Wind as an Energy Source. Aspliden C (Ed.) WMO No. 575, Geneva, Switzerland. 